\title{
Nepotismo del gobierno gutierrista: aires de familia en el poder
}

\author{
Javier Ponce ${ }^{*}$
}

\section{Juntos en el goce y la desgracia}

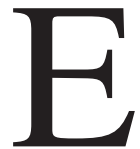

1 poder ejercido a través y en provecho familiar no es reciente en el Ecuador. No lo ha inventado el clan Gutiérrez-Borbúa. Es un antiguo uso cultural. Quizás el gobierno del coronel lo ha llevado a su clímax. O estamos frente al intento, a destiempo, de generar un nuevo grupo familiar de poder que no se reduce a los parientes más cercanos del mandatario, sino que, a través de ellos, se proyecta y ramifica. Pero aquello resulta demasiado anacrónico. Una simple parodia de un pasado de clanes familiares.

Y allí, en su anacronismo, el intento de Gutiérrez se ha desnudado hasta aparecer obsceno.

Cuando el exhibicionismo se practica sin rubor, el nepotismo se torna pornografía política. Es la obscenidad y la obesidad de la que habla Jean Baudrillard "cuando el cuerpo social pierde su regla". La transpolítica, dice este autor "es la transparencia y la obscenidad de todas las estructuras en un universo desestructurado".

¿El nepotismo, ese manejo familiar del poder, comenzó a incorporarse a la cultura política desde tiempos coloniales?

Seguramente. Basta repasar la telaraña familiar de uno de los presidentes de la Real Audiencia ${ }^{1}$, un acaudalado Sánchez de Orellana, dueño de obrajes al tiempo que funcionario de la colonia, con tres tíos paternos gobernadores o corregidores, un hermano regidor perpetuo de Latacunga y alcalde provincial que llegó a comprar la Santa Hermandad,

\footnotetext{
* Editorialista de Diario El Universo.

1 Tamar Herzog. Los ministros de la Audiencia de Quito (1650-1750) Ediciones Libri Mundi Enrique Grosse-Luemern. Quito, 1995.
} 
otro cobrador de tributos y casado con la hija del regidor perpetuo de Riobamba y un tío oidor en Quito.

Aquello que se ha vivido con impudicia desde tiempos coloniales, irrumpe, se transparenta, contagia todo el cuerpo del poder a lo largo de nuestra historia, desde la constitución misma de la República, hasta convertirse en un entramado de parentescos en cadena, de "sobrinazgos", como también califica el diccionario a los favores entre familiares. El Ecuador nace de la mano de dos venezolanos que adquieren identidad a través de lazos familiares. La quiteña Mariana Carcelén, marquesa de Solanda, ata a Antonio José de Sucre a la naciente república; y la aristócrata Mercedes Jijón Vivanco concede a Juan José Flores "la nacionalidad que le hacía falta".

"De esa manera -escribe Roberto Andrade- los ases quedaban en manos de la naciente plutocracia criolla para el complicado juego de la historia". Con aquello se consolidaba la cultura colonial, la de los presidentes de la Audiencia que tenían parientes no solo en el gobierno civil sino en el eclesiástico.

Más tarde, Juan José Flores pronosticaría la continuidad de un poder familiar, al proclamar: "Mi hijo Antonio es el llamado a hacer la ventura de esta Patria que me ha costado tantos desvelos"3. Un Antonio Flores Jijón que en sus años de gobierno "presuntuoso y grandilocuente, autor de la inolvidable pieza lírica 'Isidorito', pasea en la carroza estilo 'Imperio' que, en sus sueños de grandeza, hiciera comprar don Ignacio de Veintimilla en las antiguas cocheras de Napoleón III, después de la quiebra del segundo imperio"4.

Cuenta Roberto Andrade en su Historia del Ecuador, que en su delirio, Juan José Flores habría negociado, con la viuda del rey español Fernando VII, la reconquista del Ecuador que pasaría a ser regentada por Flores y sus descendientes. Esa práctica de los caudillos llegados desde la marginalidad, de procurarse una "limpieza de sangre" y de buscar perpetuar la propiedad sobre el poder, la practicaría a su turno un jefe montonero convertido en presidente de la República, Leonidas Plaza, al casarse con una aristócrata quiteña de apellido Lasso.

\footnotetext{
2 Roberto Andrade. Historia del Ecuador (Cuarta parte) Corporación Editora Nacional. Quito, 1984.

3 Ecuador, historia de la República. Editorial El Conejo. Quito, 1986.

4 Roberto Andrade. Ob. cit.

214
} 
Pero el ejercicio de la política también fue asunto de familia entre los contestatarios del poder. Es el caso de los "gracos" como llamó Raúl Andrade a sus antepasados Roberto, Julio y Carlos Andrade y Abelardo Moncayo (casado con Dolores Andrade durante el tiempo que permaneció refugiado en la finca familiar), que protagonizaron como un "asunto de familia" un largo combate contra el conservadorismo y la plutocracia. Si los goces del poder llegaban por vía familiar, en el caso de los Andrade la persecución a los autores de la muerte de García Moreno se extendió a toda una familia de "apestados".

Raúl Andrade traza el retrato de su familia que, desde una finca en las afueras de Otavalo, vivió las revueltas tan familiarmente, que la mayoría de sus numerosos miembros integraban el naciente liberalismo. Precisamente la muerte de la madre de los Andrade ocurrirá en momentos en que Roberto Andrade era un preso político en el panóptico de Quito, sus hermanos Modesto y Carlos estaban en la guerrilla al norte del país y Julio combatía igualmente en las provincias del centro andino.

"Desde las almenas del panóptico (Roberto) asiste, por una concesión especial, a la ceremonia del entierro (de su madre) en el vecino cementerio de San Diego" comenta Raúl Andrade.

La historia política siempre tuvo un signo familiar. Y el historiador Roberto Andrade, cuando habla de las fuerzas alfaristas que salen de Latacunga y Ambato a combatir, se refiere, con un uso alegre de los términos, de "los Fernández, los Holguín, los Pachano, los Quirola, los Martínez".

Y el propio Eloy Alfaro acabaría arrastrado y quemado junto a sus hermanos.

\section{La argolla: el modelo del nepotismo}

Un historiador identificado con los regímenes de derecha, el sacerdote jesuita José María Le Gohuir ${ }^{6}$, nos entrega un cándido retrato del nepotismo en tiempos de los presidentes Antonio Flores Jijón y Plácido Caamaño. Lo llamo cándido, porque el religioso se lamenta que la

\footnotetext{
5 Raúl Andrade. Julio Andrade, Crónica de una Vida Heroica. Quito, 1962.

6 José María Le Gohuir, S.I. Biblioteca Grupo Aymesa. Quito (sin fecha).
} 
oposición de los liberales se fundamente en algo tan natural como puede ser la presencia de aires de familia en el poder; sin embargo son ambiguas las expresiones del historiador, porque no deja de condenar el nepotismo, aunque se exageren las acusaciones.

Escribe José María Le Gohuir: “...la oposición no tardó en erguirse atrevida para entorpecer a priori todo conato de resurgimiento moderno; la burla halló sobrada materia para satirizar intenciones frustrándose a la postre por fantástico el patriótico celo del Presidente. "En el movimiento de oposición, encontrábase de antemano el Liberalismo en actitud muy hostil, animado de odio feroz en todo lo relacionado con las familias de Flores y Caamaño (emparentadas entre sí; recordemos que Jacinto Jijón y Caamaño se casó con una descendiente de Flores y hermana de Antonio. Nota de J.P.). Irritábale el que la nueva administración (Flores) mantuviera al ex presidente (Caamaño) en la Gobernación del Guayas, puesto el más importante después de la presidencia, y a don Rafael, hermano de este, en la Prefectura General de Policía, además de otro hermano del mandatario, general Reinaldo Flores, en la Comandancia del Guayas.

"Por otra parte, seguían al frente de los negocios, dueños de alguna manera del Crédito Público, los mismos financistas de la administración anterior, don Carlos Caamaño y su cuñado Leonardo Stagg, ambos relacionados con el hacendista peruano don Aníbal González Baso, sobrino político del Presidente.

"Ese círculo cerrado de deudos, en el que entraban algunos agentes amigos de Caamaño y de Flores, como don Clemente Ballén, Murrieta y otras firmas honorables, es lo que dieron en apodar no sin ningún fundamento "La Argolla", o sea una cadena cuyos cabos arrancaban y remataban en el Gabinete; cadena forjada por el secreto profesional, la reserva de familia y por el mismo interés que se presumía para todos los negocios en los miembros de esta como oligarquía política económica. Otro fin del círculo en asunto político, consistía también, según se fingía, en asegurar a Caamaño la vuelta al solio y así afianzar, como por concatenación preestablecida, una dinastía republicana y el predominio efectivo de una familia.

"El término de argolla política militante confirma la observación de no pocos viajeros, a saber que el poder del mote entre nosotros se parece a la eficacia de una arma verdadera y mortífera. "De hecho la palabra hizo fortuna, dio popularidad a la oposición económica. La exa- 
geración de cierta prensa se ejerció en ello sin piedad ni descanso, y se probaron una vez más, como en otro tiempo con Noboa y luego con Alfaro, que el nepotismo y la condescendencia para con los parientes se prestan a los más crueles desengaños, redundando finalmente en daño del Estado.

"Tal fue la acusación de que, durante todo el período usaron y abusaron sin tino liberales y conservadores y en general todos los descontentos, presumiendo y pregonando que bajo aquel velo se perpetraban peculados y fraudes sin cuento, abusos en fin que no necesitaban de ruedas, ni llegaban a probarse nunca".

\section{Buenas razones para el "sobrinazgo"}

Si intentáramos, desde el análisis político, explicar el nepotismo, nos encontraríamos con una razón sustancial: la ausencia de institucionalidad o su viciado origen. Un gran espacio de negociación de intereses sujeto a caprichos, a vivezas, a poderes heredados: ese es el precario Estado ecuatoriano. Y ante la ausencia de institucionalidad, los lazos de familia se convierten en los articuladores de los privilegios. Más aún, la vapuleada institucionalidad republicana nace a imagen y semejanza de una estructura familiar.

Allí no hay compromisos políticos perdurables, no hay programas, no hay horizontes más o menos trazados. A la ausencia de institucionalidad, se suma la informalidad, la ambigüedad con que se abordan las circunstancias... "La palabra para él, no entra dentro de lo solemne. ¡No! Cambia de idea, cambia de palabra, todo es una misma cosa" escribía allá por 1928 un poeta viajero, Henry Michaux, en su libro Ecuador?

Y Carlos de la Torre ${ }^{8}$ describe las relaciones del ciudadano con el Estado en los siguientes términos: "La gente de a pie, tanto en la Sierra como en la Costa, se relaciona con el Estado a través de relaciones personalizadas en las que tienen que recurrir a padrinos, patrones o conocidos...".

7 Henri Michaux. Ecuador (Diario de viaje). Tusquets Editores. Barcelona, 1983.

8 Carlos de la Torre Espinosa. Veinte años de populismo y democracia. Revista Iconos. Abril 2000. 
Y cuando la gente de a pie llega al poder -y el clan de los Gutiérrez Borbúa puede ser ese caso-, sabe que las oportunidades son calvas, y que debe multiplicar esa red de relaciones personalizadas para transformar su condición familiar, y asegurarse, al mismo tiempo, lealtades que van más allá de lo legal o ideológico.

Allí, en las lealtades familiares, adquieren identidad política. Se trata, por tanto, de la vieja cultura política en la que cabe, según Agustín Cueva, que "los espacios y los recursos públicos se utilicen para fines particulares. (...) En estas condiciones, no ha sido posible la construcción de un espacio público en todos los sentidos de la palabra".

$\mathrm{El}$ acceso al poder se convierte, finalmente, en la posibilidad familiar de concretar fines personales, o de conseguir, a horcajadas del familiar que llegó a ser uncido, entrar en la clase política o en las elites sociales y económicas.

El nepotismo no se presenta solo en una sociedad desarticulada desde sus orígenes. Es una pieza dentro del modo como se ha ido construyendo un Estado a base de organizar los botines de guerras intestinas, las alianzas que se han repartido los negocios, la huella dejada por dictadores mesiánicos y una legislación trazada a la luz de los escándalos, y fruto de la reacción ante un hecho de corrupción o de totalitarismo; y que, por tanto, es una legislación que hace aguas por todas partes, que sirve únicamente para los casos inéditos que la inspiraron. El nepotismo acompaña al populismo, al clientelismo, a la intolerancia que se define por lazos de amistad y enemistades viscerales. El nepotismo es, a fin de cuentas, "un elemento interno y activo de la cultura"10.

En síntesis, una cultura política de clanes y familias que, sin estructuras políticas, sin partidos, sin ideologías, no confían sino en las lealtades de sangre.

Una nación que se conforma por ondas sucesivas que reproducen círculos de desconfianza. La familia se cierra en sí misma para protegerse de las amenazas del exterior. La localidad se cierra en sí misma para protegerse de las amenazas del exterior. La nación -por la vía del ciego nacionalismo- se cierra en sí misma para protegerse de las amena-

\footnotetext{
8 Néstor García Canclini. Culturas Hibridas. Grijalbo. México, 1989.

9 Agustín Cueva. Proceso de dominación política en el Ecuador. Editorial Planeta. Quito, 1997.
} 
zas del exterior. $Y$ en ese encerramiento, cada uno encuentra su retazo de identidad.

No hay ley, no hay institucionalidad, no hay memoria ética que impida el asalto familiar del poder. Y los que van a la cabeza de ese asalto, no pueden argüir razones de estado para impedirlo. El presidente Gutiérrez no puede deshacerse de su parentela, incluso si está en riesgo su régimen.

Están allí en función de un mandato familiar.

La designación presidencial se convierte en la concesión de una licencia ilimitada por parte de la democracia, para que el presidente, investido de un derecho de corso, organice su gobierno, no desde una ideología o un partido sino desde los intereses más cercanos.

Bolívar Echeverría ${ }^{11}$ califica a este tipo de personajes -en nuestro caso mandatarios- como "alguien que no siente escrúpulos al utilizar en beneficio propio los puntos de fracaso de una forma institucional vigente, las zonas ciegas en donde ella y las normas derivadas de ella se demuestran incapaces de organizar adecuadamente el contenido social que las había reclamado y al que ellas aparentemente responden".

Si todo se ha de conseguir a través del compadrazgo, de los vínculos de amistad, de los parentescos, es evidente que el nepotismo se convertirá en el mecanismo de una curiosa reciprocidad, pero que si ocurre entre familias tradicionalmente vinculadas al poder, posiblemente se pasa por alto.

No así si se trata de advenedizos. El asunto se vuelve más descarnado y grotesco si el grupo familiar que lo protagoniza no ha pertenecido a las llamadas "grandes familias", sino que viene desde abajo, cargando todas las frustraciones, los delirios insatisfechos, los sueños de telenovela.

En ese sentido, hay dos personajes en este régimen, cada uno en su estilo, pero por igual cándidos, que son la caricatura de ese conjunto de "delirios de familia", y que se manifiestan en expresiones excéntricas, circenses a veces: Napoleón Villa y Ximena Bohórquez.

Ellos resumen, en el plano de la parodia, las características de un poder familiar que aparece incompatible con la democracia, incompati-

11 Bolívar Echeverría. Las ilusiones de la modernidad. Editorial Tramasocial. México, 2001. 
bilidad pasada por alto, si ocurre en las elites políticas tradicionales. ¿O acaso se montó un escándalo político mayor como los que acompañan todos los gestos de Villa, cuando el presidente Sixto Durán sacó del país, en el avión presidencial, a un sobrino suyo requerido por la justicia?

\section{El derecho a heredar el poder}

La endogamia podría ser otra versión del nepotismo entre nosotros. El carácter endogámico del poder político. Ya lo señalé en el caso de Juan José Flores predestinando la presidencia de su hijo Antonio, protagonista a su vez del más sonado caso de nepotismo en cadena: la llamada "Argolla".

La política ecuatoriana recuerda innumerables casos de vinculación política familiar. Galo Plaza "heredó" el poder de su padre, el General Leonidas Plaza. Los Arosemena tienen a su haber tres presidentes de la República. Uno de los elementos que desató la persecución final a Alfaro fueron las pretensiones presidenciales de su hermano Flavio. Cuentan que, en secreto, Gustavo Noboa se colocaba de vez en cuando, frente a un espejo, la banda presidencial que llevó su antecesor Diego Noboa. Manuel Jijón Flores heredó el partido conservador de su padre Jacinto. Resulta inevitable encontrar paralelismos entre la capacidad de pescar a río revuelto de Fabián Alarcón con la de su padre Ruperto (mejor conocido como Rupango). Y en las urnas, el pueblo ecuatoriano le dio el pésame a Cecilia Calderón por el asesinato de su padre; al tiempo que un Asaad Bucaram, al que la clase política le negó el derecho a llegar a la presidencia, se buscó un sobrino político que coseche sus votos, Jaime Roldós, para que ocurrida la muerte de este, su hermano León llegue a la vicepresidencia de modo de "garantizar" en el régimen de Hurtado la vigencia del pensamiento del presidente desaparecido.

En una reciente investigación sobre la constitución del parlamento, se establece que más del cincuenta por ciento de los diputados que estuvieron en el Congreso en el período anterior, tenían parientes en la actividad política. El ochenta por ciento de la Democracia Popular lo tenía, y el cuarenta por ciento de los socialcristianos registraba la presencia de por lo menos tres parientes en política. 
En síntesis, el nuestro es un país en el cual el nepotismo se ha alimentado de la ausencia de institucionalidad, y las instituciones se han tejido en torno a las familias.

La familia Gutiérrez-Borbúa ejecuta, con sus actos, una oda pública al nepotismo. Y es que el Estado puede ser una empresa familiar que colma y rebasa incluso los más audaces sueños. Hay para todas las ambiciones allí, tal como lo cuenta Nicolás Maquiavelo a propósito de la ambición de papas como Nicolás III (s. XIII), que para satisfacerla empezaron a compartirla con sus "sobrinos" (nipoti) e hijos: "esta costumbre, nunca antes mencionada sobre los sobrinos y parientes de algún pontífice, ha colmado toda la historia posterior, llegando hasta los hijos, que si hasta ahora los habían hecho príncipe, pensarán dejarles el papado hereditario" escribe Maquiavelo ${ }^{12}$.

Y en eso consiste la obscenidad, nos dice Jean Baudrillard*: "Todas las estructuras invertidas, exhibidas, todas las operaciones hechas visibles".

Un acto de pornografía política de los Gutiérrez Burbúa, que, quizás fue la culminación de una vieja costumbre. Un gesto de desparpajo, un salto en el vacío que, tal vez, imponga límites a esa costumbre, pues los ecuatorianos legislamos en materia de ética como si la Ley fuese la remisión del pecado.

\footnotetext{
12 Nicolás Maquiavelo. Historias florentinas.

*Ob. Cit.
} 
